\title{
Pengaruh Motivasi Ekstrinsik terhadap Tingkat Kepatuhan Pemakai Gigi Tiruan Lepasan di Kelurahan Batu Kota
}

\author{
${ }^{1}$ Nurwahid P. Iksan \\ ${ }^{1}$ Vonny N. S. Wowor \\ ${ }^{2}$ Damajanty H. C. Pangemanan \\ ${ }^{1}$ Program Studi Pendidikan Dokter Gigi Fakultas Kedokteran \\ ${ }^{2}$ Bagian Fisiologi Fakultas Kedokteran \\ Universitas Sam Ratulangi Manado \\ Email: nurwahid.putra7@gmail.com
}

\begin{abstract}
The purpose of artificial teeth is to replace the lost teeth and to maintain the function of mastication and speech. Lack of personal mindset to wear denture leads to poor compliance. Motivation can affect personal mindset or attitude. Extrinsic motivation can make the denture wearers become more compliant. This study was aimed to determine the effect of extrinsic motivation on the compliance of removable denture wearers as well as the compliance level of the denture wearers at Batu Kota Manado. This was an analytical descriptive study using a cross sectional design. There were 81 respondents in this study obtained by using purposive sampling method. We used questionnaires which were already tested in terms of validity and reliability. Data were analyzed by using the simple regression test. The results showed that the extrinsic motivation of $60.5 \%$ respondents belonged to moderate category, $23.5 \%$ to high category, and $16 \%$ to low category. Based on the compliance level, $55.6 \%$ of respondents were in moderate level, $24.7 \%$ in low level, and $19.7 \%$ in high level. The simple regression test showed a $P$ value of $0.000(<0.05)$. Conclusion: Extrinsic motivation and compliance level of removable denture wearers were generally moderate. Moreover, extrinsic motivation could influence the level of compliance of the removable denture wearers at Batu Kota Manado.
\end{abstract}

Keywords: extrinsic motivation, compliance, removable denture

\begin{abstract}
Abstrak: Pemakaian gigi tiruan bertujuan untuk menggantikan gigi yang hilang dan mence-gah terjadinya gangguan fungsi pengunyahan hingga fungsi bicara. Kurangnya pola pikir seseorang terhadap pemakaian gigi tiruan menyebabkan kepatuhan yang rendah. Motivasi dapat memengaruhi pola pikir atau sikap seseorang. Motivasi ekstrinsik dapat menjadikan pengguna gigi tiruan menjadi taat dan patuh. Penelitian ini bertujuan untuk mengetahui pengaruh motivasi ekstrinsik terhadap tingkat kepatuhan pemakai gigi tiruan di Kelurahan Batu Kota. Jenis penelitian ialah deskriptif analitik dengan desain potong lintang. Sampel penelitian sebanyak 81 responden diperoleh dengan metode purposive sampling. Instrumen penelitian berupa kuesioner yang telah dilakukan uji validitas dan reliabilitas. Analisis hasil penelitian menggunakan uji statistik regresi sederhana. Hasil penelitian menunjukkan bahwa 60,5\% masyarakat Kelurahan Batu Kota memiliki motivasi ekstrinsik sedang, 23,5\% tinggi, dan sebanyak16\% rendah. Sebanyak 55,6\% masyarakat memiliki tingkat kepatuhan sedang, 24,7\% rendah, dan 19,7\% tinggi. Hasil uji regresi sederhana mendapatkan $P=0,000 \quad(<0,05)$. Simpulan: Motivasi ekstrinsik masyarakat pemakai gigi tiruan lepasan dan tigkat kepatuhan umumnya tergolong sedang. Terdapat pengaruh motivasi ekstrinsik terhadap tingkat kepatuhan pemakai gigi tiruan lepasan di Kelurahan Batu Kota Manado.
\end{abstract}

Kata kunci: motivasi ekstrinsik, kepatuhan, gigi tiruan lepasan 
Gigi merupakan salah satu bagian tubuh penting yang memiliki berbagai fungsi, mulai dari fungsi bicara, fungsi pengunyahan hingga fungsi estetik. ${ }^{1}$ Oleh karena itu kesehatan gigi dan mulut sebagai bagian integral dari kesehatan secara umum penting untuk diperhatikan. Dewasa ini kesehatan gigi dan mulut masih menjadi permasalahan di berbagai negara. ${ }^{2}$ Kurangnya pemeliharaan kesehatan gigi dan mulut merupakan salah satu penyebab meningkatnya masalah kesehatan.

Masalah kesehatan gigi dan mulut seperti karies dan penyakit periodontal yang terus meningkat menjadi salah satu faktor penyebab hilangnya gigi. ${ }^{3}$ Kehilangan gigi yang dibiarkan begitu saja akan menimbulkan berbagai masalah seperti gangguan fungsi bicara dan pengunyahan. Selain itu kehilangan gigi juga secara tidak langsung berdampak pada kesehatan umum dan emosi seseorang. ${ }^{4,5}$ Oleh karena itu dibutuhkan pemakaian gigi tiruan untuk menggantikan gigi yang hilang dan mencegah terjadinya gangguan fungsi pengunyahan dan fungsi bicara. ${ }^{2}$

Data hasil Riset Kesehatan Dasar (RISKESDAS) 2007 menunjukkan persentasi pengguna gigi tiruan di Indonesia mencapai $4,6 \%$ sedangkan prevalensi pengguna gigi tiruan yang ada di Sulawesi Utara sebesar $7,1 \% .^{6}$ Data tersebut terus meningkat seiring dengan bertambahnya usia. Data World Health Organization (WHO) 2012 tentang kesehatan gigi dan mulut menunjukkan persentasi kehilangan gigi di Indonesia pada umur 35-44 tahun sebesar $0,4 \%$ dan meningkat pada umur 65 tahun ke atas sebesar $17,6 \%$ yang akan membuat kebutuhan akan pemakaian gigi tiruan semakin meningkat. ${ }^{7}$

Pemakaian gigi tiruan lepasan memiliki banyak manfaat, antara lain seperti memulihkan fungsi pengunyahan hingga fungsi estetik. ${ }^{2}$ Namun pemakaian gigi tiruan dapat pula menimbulkan ketidaknyamanan pada pemakai gigi tiruan saat digunakan. Masalah yang umum dikeluhkan saat memakai gigi tiruan ialah rasa nyeri atau longgar yang dapat menyebabkan pasien malas atau tidak termotivasi untuk menggunakan gigi tiruannya. Faktor lainnya ialah kurangnya pola pikir seseorang terhadap pemakaian gigi tiruan. ${ }^{8}$ Motivasi merupakan salah satu faktor yang dapat memengaruhi pola pikir atau sikap seseorang.

Motivasi adalah dorongan seseorang yang dapat menimbulkan tingkat persistensi dan antusiasme individu dalam melaksanakan suatu kegiatan, baik yang bersumber dari dalam diri individu itu sendiri yang disebut motivasi intrinsik maupun dari luar diri individu itu sendiri yang disebut motivasi ekstrinsik. ${ }^{9}$ Faktor yang memengaruhi motivasi ekstrinsik antara lain berupa dorongan dari keluarga, lingkungan atau adanya imbalan untuk melakukan sesuatu. ${ }^{10}$

Motivasi ekstrinsik dapat mendorong pemakai gigi tiruan lepasan menjadi taat dan patuh. Kepatuhan pemakai gigi tiruan lepasan adalah bentuk perilaku pemakai gigi tiruan sesuai dengan ketentuan atau anjuran yang diberikan oleh dokter gigi. Pemakai gigi tiruan lepasan bersikap patuh kepada dokter gigi karena adanya sikap positif terhadap perawatan yang dilakukan. Sikap positif ini muncul antara lain akibat adanya dorongan untuk sembuh, serta ancaman atau berupa reward yang diberikan. Pemakai gigi tiruan lepasan yang patuh pada anjuran dokter gigi dapat dikatakan memiliki motivasi ekstrinsik yang tinggi saat menggunakan gigi tiruan lepasan. ${ }^{11}$

\section{METODE PENELITIAN}

Jenis penelitian ini ialah deskriptif analitik dengan desain potong lintang. Penelitian ini dilakukan di Kelurahan Batu Kota Kecamatan Malalayang Manado pada bulan Mei 2018.

Populasi penelitian ialah seluruh masyarakat Kelurahan Batu Kota Kecamatan Malalayang yang menggunakan gigi tiruan lepasan yakni sebanyak 355 orang, dihitung menggunakan prevalensi pengguna gigi tiruan di Sulawesi Utara sebesar 7,1\%. Besar sampel pada penelitian ini dihitung dengan menggunakan rumus Slovin sebesar 81 orang. Kriteria inklusi ialah mengguna- 
kan gigi tiruan sebagian lepasan (GTSL) dan gigi tiruan penuh (GTP), berdomisili di Kelurahan Batu Kota dibuktikan dengan KTP setempat, dan gigi tiruan lepasan yang dibuat oleh dokter gigi, jenis kelamin lakilaki dan perempuan, berusia 15 tahun ke atas, dan berkomunikasi dengan baik. Kriteria eksklusi tidak berada di tempat saat penelitian berlangsung dan tidak kooperatif selama proses penelitian. Teknik pengambilan sampel yang digunakan dalam penelitian ini menggunakan purposive sampling. Instrumen penelitian terdiri dari dua kuesioner, yaitu kuesioner motivasi ekstrinsik dan kuesioner kepatuhan pemakai gigi tiruan.

Pengambilan data dilakukan dengan cara mendatangi ke rumah-rumah responden dan menunjukan izin penelitian dan surut pernyataan menjadi objek penelitian kepada responden yang bersedia. Responden diminta untuk mengisi kuesioner yang telah disediakan.

Analisis data menggunakan uji regresi sederhana dengan bantuan program komputer SPSS versi 23. Data dianalisis secara univariat untuk memperoleh gambaran dan distribusi setiap variabel yang diteliti, baik variabel bebas maupun terikat dan Dianalisis juga secara bivariat untuk mengetahui interaksi dari dua variabel.

\section{HASIL PENELITIAN}

Tabel 1 menunjukkan bahwa responden terbanyak berjenis kelamin perempuan yang berjumlah 62 orang (76,5\%), sedangkan yang berjenis kelamin laki-laki berjumlah 19 orang $(23,5 \%)$.

Tabel 1. Distribusi frekuensi responden berdasarkan jenis kelamin

\begin{tabular}{ccc}
\hline Jenis kelamin & n & \% \\
\hline Perempuan & 62 & 76,5 \\
Laki-laki & 19 & 23,5 \\
Total & 81 & 100 \\
\hline
\end{tabular}

Tabel 2 menunjukkan bahwa responden terbanyak berusia 48-58 tahun yang berjumlah 34 orang (42\%), dan responden paling sedikit berusia 26-36 tahun yang berjumlah 5 orang $(6,2 \%)$. Tidak terdapat responden yang berusia 15-25 tahun dan di atas 70 tahun.

Tabel 2. Distribusi frekuensi responden berdasarkan usia

\begin{tabular}{ccc}
\hline $\begin{array}{c}\text { Usia } \\
\text { (tahun) }\end{array}$ & $\mathbf{n}$ & $\boldsymbol{\%}$ \\
\hline $15-25$ & 0 & 0 \\
$26-36$ & 5 & 6,2 \\
$37-47$ & 16 & 19,7 \\
$48-58$ & 34 & 42 \\
$59-69$ & 26 & 32.1 \\
$>70$ & 0 & 0 \\
Total & 81 & 100 \\
\hline
\end{tabular}

Tabel 3 menunjukkan bahwa responden terbanyak berpendidikan SMA yang berjumlah 60 orang $(74,1 \%)$, dan yang paling sedikit yaitu berpendidikan SMP berjumlah 3 orang $(3,7 \%)$.

Tabel 3. Distribusi frekuensi responden berdasarkan pendidikan

\begin{tabular}{ccc}
\hline Pendidikan & n & \% \\
\hline SD & 8 & 9,9 \\
SMP & 3 & 3,7 \\
SMA & 60 & 74,1 \\
S1/diatasnya & 10 & 12,3 \\
Total & 81 & 100 \\
\hline
\end{tabular}

Tabel 4 menunjukkan bahwa responden terbanyak yang memakai gigi tiruan jenis GTSL sebanyak 70 orang $(86,4 \%)$ dan responden yang menggunakan gigi tiruan jenis GTP sebanyak 11 orang $(13,6 \%)$.

Tabel 4. Distribusi frekuensi responden berdasarkan jenis gigi tiruan lepasan yang dipakai

\begin{tabular}{ccc}
\hline Jenis gigi tiruan & n & \% \\
\hline GTSL & 70 & 86,4 \\
GTP & 11 & 13,6 \\
Total & 81 & 100 \\
\hline
\end{tabular}

Berdasarkan hasil penelitian yang dilakukan, diperoleh distribusi frekuensi penilaian responden berdasarkan kuesioner motivasi ekstrinsik pemakai gigi tiruan lepasan yang diperlihatkan pada Tabel 5 
Tabel 5. Distribusi frekuensi penilaian kuesioner motivasi ekstrinsik

\begin{tabular}{|c|c|c|c|c|c|c|c|}
\hline No & Pertanyaan & TT & KT & $\mathbf{T}$ & ST & AST & Skor \\
\hline 1 & $\begin{array}{l}\text { Anggapan dari anggota keluarga/masyarakat mem- } \\
\text { punyai gigi ompong adalah sesuatu yang tidak } \\
\text { wajar sehingga gigi tiruan yang ada harus diguna- } \\
\text { kan secara rutin }\end{array}$ & 19 & 21 & 14 & 18 & 9 & 220 \\
\hline 2 & $\begin{array}{l}\text { Keluarga/komunitas menyarankan/mendorong un- } \\
\text { tuk menggunakan gigi tiruan secara rutin untuk } \\
\text { menggantikan fungsi gigi yang hilang }\end{array}$ & 50 & 22 & 5 & 3 & 1 & 126 \\
\hline 3 & $\begin{array}{l}\text { Media cetak/media online/media elektronik mem- } \\
\text { berikan informasi tentang pentingnya pemakaian } \\
\text { gigi tiruan secara rutin untuk menggantikan fungsi } \\
\text { gigi yang hilang }\end{array}$ & 1 & 12 & 9 & 30 & 29 & 317 \\
\hline 4 & $\begin{array}{l}\text { Media cetak/media online/media elektronik mem- } \\
\text { berikan informasi tentang dampak bagi pengguna } \\
\text { gigi tiruan apabilai gigi tiruan tidak digunakan } \\
\text { secara rutin. }\end{array}$ & 10 & 17 & 15 & 22 & 17 & 262 \\
\hline 5 & $\begin{array}{l}\text { Adanya penyuluhan dari fasilitas kesehatan peme- } \\
\text { rintah (puskesmas)/instansi lain tentang pentingnya } \\
\text { menggunakan gigi tiruan secara rutin untuk } \\
\text { menggantikan fungsi gigi yang hilang }\end{array}$ & 0 & 5 & 17 & 37 & 22 & 319 \\
\hline 6 & $\begin{array}{l}\text { Dokter gigi yang melakukan perawatan gigi tiruan } \\
\text { menjelaskan tentang pentingnya penggunaan gigi } \\
\text { tiruan secara rutin pada pengguna gigi tiruan. }\end{array}$ & 6 & 17 & 28 & 24 & 6 & 250 \\
\hline 7 & $\begin{array}{l}\text { Gigi tiruan yang dibuat oleh fasilitas kesehatan } \\
\text { nyaman untuk digunakan dan dapat menggantikan } \\
\text { fungsi gigi yang hilang }\end{array}$ & 1 & 12 & 28 & 34 & 6 & 275 \\
\hline & Total & & & & & & 1769 \\
\hline
\end{tabular}

Kategori hasil pengukuran secara kontinum dapat dilihat pada skala berikut :

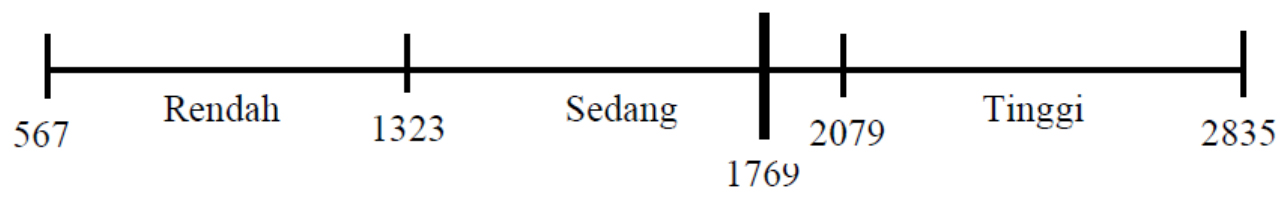

Tabel 6. Distribusi frekuensi responden berdasarkan motivasi ekstrinsik pemakai gigi tiruan

\begin{tabular}{ccc}
\hline Motivasi ekstrinsik & n & \% \\
\hline Rendah & 13 & 16,0 \\
Sedang & 49 & 60,5 \\
Tinggi & 19 & 23,5 \\
Total & 81 & 100 \\
\hline
\end{tabular}

Tabel 7. Distribusi frekuensi penilaian kuesioner kepatuhan pemakai gigi tiruan lepasan

\begin{tabular}{clcccccc}
\hline No & \multicolumn{1}{c}{ Pertanyaan } & TP & KP & P & SP & ASP & Skor \\
\hline 1 & $\begin{array}{l}\text { Gigi tiruan digunakan sesuai petunjuk/ anjuran } \\
\text { dokter gigi yang merawat. }\end{array}$ & 13 & 24 & 16 & 25 & 3 & 224 \\
2 & $\begin{array}{l}\text { Gigi tiruan tidak digunakan terus menerus, tetapi } \\
\text { hanya digunakan pada siang hari saja. }\end{array}$ & 6 & 19 & 6 & 40 & 10 & 272 \\
3 & $\begin{array}{l}\text { Gigi tiruan yang digunakan dibersihkan minimal } \\
\text { 2 kali sehari }\end{array}$ & 2 & 12 & 8 & 50 & 9 & 295 \\
4 & Gigi tiruan dibersihkan dengan menggunakan & 15 & 28 & 14 & 21 & 3 & 212
\end{tabular}


sikat gigi berbulu halus.

5 Gigi tiruan dibersihkan dengan menggunakan air bersih dan deterjen cair.

$\begin{array}{lllll}0 & 3 & 8 & 56 & 14\end{array}$

324

6 Sebelum tidur pada malam hari, gigi tiruan yang sudah dibersihkan direndam dalam air bersih/ cairan pembersih

7 Sebelum digunakan kembali gigi tiruan yang direndam dicuci bersih terlebih dahulu dan dibilas.

8 Kunjungan rutin ke dokter gigi dilakukan 3-6 bulan sekali

Total

$\begin{array}{llllll}2 & 12 & 6 & 47 & 14 & 302\end{array}$

$\begin{array}{llllll}31 & 33 & 6 & 10 & 1 & 160\end{array}$

$\begin{array}{llllll}41 & 16 & 14 & 10 & 0 & 155\end{array}$

1944

Kategori data hasil pengukuran kepatuhan pemakai gigi tiruan secara kontinum dapat dilihat pada skala berikut ini :

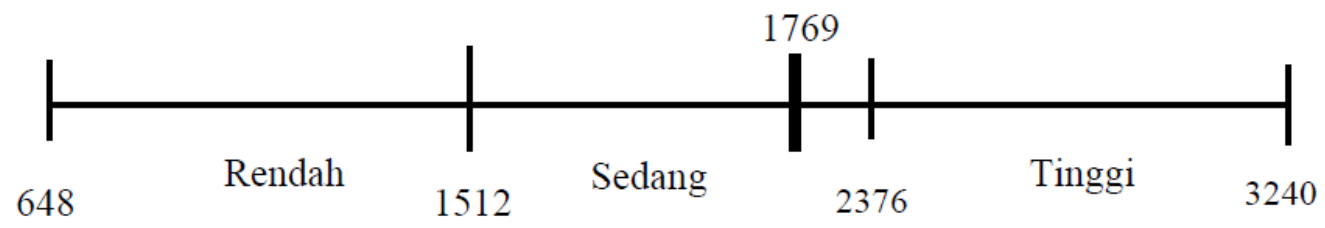

\begin{tabular}{ccc}
\hline Tingkat kepatuhan & $\mathbf{n}$ & $\boldsymbol{\%}$ \\
\hline Rendah & 20 & 24,7 \\
Sedang & 45 & 55,6 \\
Tinggi & 16 & 19,7 \\
Total & 81 & 100 \\
\hline
\end{tabular}

Tabel 9. Distribusi kategori motivasi ekstrinsik terhadap tingkat kepatuhan pemakai gigi tiruan

\begin{tabular}{|c|c|c|c|c|c|c|c|}
\hline \multirow{2}{*}{$\begin{array}{l}\text { Motivasi } \\
\text { ekstrinsik }\end{array}$} & \multicolumn{6}{|c|}{ Kepatuhan pemakai gigi tiruan lepasan } & \multirow{2}{*}{ Total } \\
\hline & Rendah & $\%$ & Sedang & $\%$ & Tinggi & $\%$ & \\
\hline Rendah & 10 & 76,9 & 2 & 15,4 & 2 & 15,4 & 13 \\
\hline Sedang & 10 & 20,4 & 35 & 71,4 & 4 & 8,2 & 49 \\
\hline Tinggi & 0 & 0 & 8 & 42,1 & 11 & 57,9 & 19 \\
\hline Total & & & & & & & 81 \\
\hline
\end{tabular}

Tabel 10. Output uji regresi sederhana

\begin{tabular}{|c|c|c|c|c|c|c|}
\hline \multirow{2}{*}{\multicolumn{2}{|c|}{ Model }} & \multicolumn{2}{|c|}{ Unstandardized Coefficients } & \multirow{2}{*}{$\begin{array}{c}\text { Standardized } \\
\text { Coefficients } \\
\text { Beta }\end{array}$} & \multirow[t]{2}{*}{$\mathbf{T}$} & \multirow[t]{2}{*}{ Sig. } \\
\hline & & $\mathrm{B}$ & Std. Error & & & \\
\hline 1 & (Constant) & .229 & 1.811 & & & .900 \\
\hline
\end{tabular}

a. Dependent Variable: $\mathrm{Y}$

\section{BAHASAN}

Hasil penelitian ini menunjukkan bahwa responden terbanyak berjenis kelamin perempuan $(76,5 \%)$ dibandingkan yang berjenis kelamin laki-laki (23,5\%). Hal ini mungkin dikarenakan responden perempuan lebih berminat mencari perawatan dan lebih peduli terhadap kesehatan gigi dan mulut, di samping itu memakai gigi tiruan merupakan salah satu cara untuk memperbaiki penampilannya. ${ }^{12,13}$ Hal ini sejalan dengan dengan penelitian oleh 
Agtina $^{14}$ yang menunjukkan bahwa persentase pemakai gigi tiruan yang berjenis kelamin perempuan di Indonesia lebih banyak dibandingkan laki-laki.

Responden terbanyak berada pada rentang usia 48-58 tahun $(42,0 \%)$. Kelompok rentang usia tersebut merupakan kelompok usia pertengahan yang lebih rentan mengalami kerusakan bahkan kehilangan gigi oleh karena lebih banyak digunakan atau difungsikan seiring dengan bertambahnya usia. ${ }^{15}$ Di samping itu, rentang usia tersebut merupakan kelompok usia produktif yang memerlukan perawatan kesehatan serta estetik yang baik. Kehilangan gigi akan membuat seseorang merasa kurang percaya diri untuk bersosialisasi dan beraktifitas. Hal ini sesuai dengan hasil penelitian Fernatubun et al. ${ }^{13}$ yang menunjukkan bahwa kelompok usia serupa merupakan responden terbanyak yang memakai gigi tiruan.

Sebagian besar $(74,1 \%)$ responden memiliki tingkat pendidikan SMA, diikuti dengan tingkat pendidikan sarjana atau di atasnya sebesar 12,3\%. Gambaran ini menunjukkan sebagian besar responden memiliki tingkat pendidikan yang dapat dikatakan cukup baik. Pendidikan yang cukup baik membuat responden akan lebih mudah memahami dan lebih peduli terhadap kesehatan gigi dan mulut oleh karena pengetahuan yang dimilikinya. Hal ini sejalan dengan penelitian yang dilakukan oleh Mokoginta et al. ${ }^{16}$ di Kotamobagu yang menyatakan adanya pengaruh tingkat pendidikan terhadap pemeliharan gigi tiruan. Semakin tinggi tingkat pendidikan maka semakin banyak pengetahuan dengan daya serap terhadap informasi yang semakin tinggi. Responden dengan pendidikan tingkat SMA umumnya sudah memiliki pengetahuan yang cukup untuk kesehatan gigi dan mulut. Adanya pemahaman pengetahuan tentang pentingnya kesehatan gigi dan mulut, akan membuat responden yang mengalami kehilangan gigi memutuskan untuk memakai gigi tiruan. ${ }^{16}$

Jenis gigi tiruan yang dipakai responden terbanyak ialah gigi tiruan jenis GTSL sebanyak 70 orang $(86,4 \%)$ dan jenis GTP sebanyak 11 orang $(13,6 \%)$. Hal ini sejalan dengan data Badan Pusat Statistik Kota Manado Update terakhir 18 Agustus 2017, yang menunjukkan bahwa komposisi penduduk berusia 15 tahun hingga usia 54 tahun jumlahnya jauh lebih banyak dari jumlah penduduk berusia di atas 55 tahun. Perhitungan kasar menunjukkan perbandingan kira-kira 1:5. ${ }^{17}$ Data yang diperoleh menunjukkan kelompok usia terbesar ialah rentang usia 20 hingga 24 tahun. Dengan demikian tidak mengherankan jika jumlah responden yang menggunakan GTP jumlahnya jauh lebih sedikit dibandingkan penguna GTSL. Penelitian yang dilakukan oleh Prabhu et al. ${ }^{18}$ menunjukkan pada kelompok usia dewasa paling tinggi mengalami kehilangan gigi sebagian, baik pada gigi anterior maupun posterior. Dengan demikian tuntutan mereka terhadap perbaikan estetik juga tinggi karena berada pada usia produktif.

Data pada Tabel 5 menampilkan skor penilaian masing-masing pernyataan dalam kuesioner motivasi ekstrinsik, dimana pada pernyataan nomor 1 dan nomor 2 menunjukkan peran dukungan keluarga responden. Dukungan keluarga yang merupakan lingkungan terdekat individu, merupakan sumber motivasi yang sangat kuat apabila keluarga memiliki pemahaman dan persepsi yang benar tentang gigi tiruan. ${ }^{19,20}$ Adanya persepsi yang benar yang dilandasi oleh pengetahuan yang benar tentang fungsi gigi tiruan serta dampaknya apabila tidak digunakan, akan menimbulkan motivasi yang akan mendorong responden untuk menggunakan gigi tiruannya secara rutin setiap hari pada waktu siang hari sesuai anjuran dokter yang merawat. Hal ini sesuai dengan penelitian yang dilakukan oleh Oftedal $^{21}$ yang menyatakan ketika seorang termotivasi dengan adanya rangsangan dari luar yaitu dukungan keluarga, lingkungan dan sosial akan membentuk suatu harapan yang memengaruhi respon sehingga menghasilkan sikap atau perilaku dalam hal ini pemakaian gigi tiruan yang rutin yang akan bertahan lama atau bersifat berkelanjutan.

Hasil yang diperoleh pada Tabel 5 
memaparkan bahwa lebih dari 50\% responden tidak termotivasi serta sebagian kurang termotivasi dari keluarga. Sebagian keluarga atau kira-kira 50\% keluarga masih belum menganggap bahwa tidak mempunyai gigi sebagai sesuatu yang tidak wajar, sehingga kalaupun ada anggota keluarga yang menggunakan gigi tiruan dan tidak menggunakannya kemungkinan besar, tidak dianggap sebagai sesuatu yang harus 'dipaksakan'. Kondisi ini mungkin disebabkan karena pengetahuan yang dimiliki keluarga berkaitan dengan penggunaan gigi tiruan masih minim. ${ }^{16}$

Pernyataan nomor 3 dan nomor 4 pada Tabel 5 menunjukkan peran media dalam memberikan motivasi ekstrinsik pada pemakai gigi tiruan. Saat ini media elektronik sudah berkembang dengan pesat, demikian juga dengan media internet. ${ }^{22}$ Pintu pengetahuan sudah sangat terbuka. Berbagai informasi termasuk informasi berkaitan dengan penggunaan gigi tiruan dapat diakses dengan mudah lewat media elektronik, media cetak, media internet. Adanya berbagai informasi yang diperoleh responden mengenai pentingnya pemakaian gigi tiruan secara rutin dan dampak dari pemakaian gigi tiruan yang tidak rutin memberikan pengetahuan dan pemahaman kepada responden, dan pada akhirnya meningkatkan motivasi responden untuk menggunakan gigi tiruannya sesuai anjuran secara rutin. Hal ini dapat dilihat dari hasil yang ada di Tabel 5, dimana sebagian besar responden termotivasi hingga amat sangat termotivasi oleh informasi berkaitan dengan penggunaan gigi tiruan yang ada di media cetak, elektronik, online, hingga media internet. $^{23}$

Pernyataan nomor 5, 6, dan 7 pada Tabel 5 menggambarkan tentang peran fasilitas kesehatan. Hasil yang ada menunjukkan sebagian besar responden termotivasi hingga amat sangat termotivasi oleh fasilitas kesehatan baik sarana dan prasarana dalam peranannya memberikan dan meningkatkan motivasi responden dalam menggunakan gigi tiruannya. Adanya dukungan puskesmas dalam programprogram promotif dan preventif serta keterlibatan petugas kesehatan dalam memberikan informasi tentang pentingnya menggunakan gigi tiruan secara rutin pada siang hari akan membangkitkan motivasi responden untuk menggunakannya secara rutin sesuai anjuran. ${ }^{24}$ Di samping itu peran dokter gigi yang melakukan perawatan pembuatan gigi tiruan dalam memberikan edukasi lewat informasi yang diberikan berkaitan dengan pemakaian gigi tiruan akan membangkitkan motivasi responden dalam menggunakan gigi tiruan sesuai anjuran dokter gigi yang merawatnya. ${ }^{25}$ Menurut sebagian besar responden, petugas kesehatan selalu memberikan informasi yang cukup berkaitan dengan gigi tiruan. Selain itu, mudahnya akses jalan ke fasilitas kesehatan dan adanya kegiatan puskesmas yang rutin dilakukan di daerah responden menambah meningkatkan pengetahuan yang membentuk perilaku responden. Pemahaman yang ada meningkatkan motivasi responden.

Data hasil pengukuran motivasi ekstrinsik responden dalam pemakaian gigi tiruan lepasan, menunjukkan rata-rata sebagian besar $(60,5 \%)$ masuk pada kategori sedang. Motivasi adalah dorongan, baik dari dalam maupun dari luar diri manusia untuk menggerakkan dan mendorong sikap dan perubahan perilakunya. Motivasi ekstrinsik ini didasarkan dari faktor eksternal individu yang bersifat psikologi dan sebagai akibat dari informasi dan hasil pengamatan suatu objek yang melahirkan persepsi sehingga individu dapat terdorong untuk berbuat atau melakukan sesuatu. ${ }^{26}$ Faktor yang berasal dari luar diri dapat ditimbulkan oleh berbagai sumber dari lingkungannya serta dukungan dari orangorang yang berasal di sekitarnya atau faktor-faktor lain yang sangat kompleks seperti dukungan dari keluarga, adanya media atau informasi dan ketersediaan fasilitas kesehatan. Hasil di atas menunjukkan bahwa sumber motivasi terbesar bagi responden diperoleh dari media cetak, online, elektronik, hingga media internet. Kemajuan teknologi ikut menunjang tingginya pemanfaatan media-media ini sebagai sumber informasi yang dapat memotivasi 
responden. Faktor keluarga yang memiliki peran yang belum terlalu besar mungkin terkait dengan pengetahuan yang dimiliki. Faktor yang bisa memengaruhi tingkat pengetahuan yakni tingkat pendidikan. Memang pada penelitian ini tidak diambil data latar belakang pendidikan keluarga, namun dari hasil yang ada dimana sebagian besar $(74,1 \%)$ berpendidikan SMA kurang lebih merupakan representasi tingkat pendidikan keluarga. Hasil penelitian yang dilakukan oleh Febrianto et al. $^{27}$ di Yogyakarta menunjukkan $63,2 \%$ responden dengan status ekonomi tinggi memiliki tingkat pengetahuan yang tinggi $(86,8 \%)$.

Hasil penelitian yang disajikan pada Tabel 7 menunjukkan sebagian besar atau di atas 50\% responden sudah mengikuti anjuran dokter gigi yang merawatnya, dimana gigi tiruan digunakan siang hari saja, dibersihkan minimal 2 kali sehari, dipelihara dan dijaga kebersihannya dengan sikat, air, dan deterjen; namun masih lebih dari 50\% membersihkannya tanpa menggunakan sikat yang halus serta sebagian besar tidak mencuci dan membilas sebelum menggunakan gigi tiruan kembali setelah direndam. Kemungkinan besar hal ini disebabkan karena responden menganggap gigi tiruan dalam keadaan bersih, karena sebelum direndam sudah dibersihkan terlebih dahulu.

Tabel 8 memaparkan bahwa sebagian besar $(55,6 \%)$ responden pemakai gigi tiruan lepasan rata-rata memiliki tingkat kepatuhan sedang. Hasil ini menunjukkan bahwa sebagian besar responden sudah memiliki perilaku yang cukup berkaitan dengan pemakaian gigi tiruan, dimana hal ini didasari oleh suatu pemahaman yang terbentuk dari pengetahuan. ${ }^{16}$ Kepatuhan dalam memakai gigi tiruan lepasan ini sangat diperlukan untuk menghindari dampak akibat tidak rutinnya memakai gigi tiruan. $^{2}$ Adapun tujuan dari kepatuhan dalam penelitian berkaitan dengan anjuran petugas kesehatan agar responden memakai dan menjaga kebersihan gigi tiruan sesuai anjuran yang disarankan. Peneliti berasumsi kepatuhan responden berada pada kategori sedang atau cukup erat hubungannya dengan tingkat pendidikan responden yang sebagian besar berpendidikan SMA. Individu lulusan SMA umumnya sudah cukup memiliki pengetahuan, termasuk pengetahuan yang berhubungan dengan pemakaian gigi tiruan. Hal ini sejalan dengan penelitian Mokoginta et al. ${ }^{16}$ di Kotamobagu mengenai pengaruh tingkat pendidikan terhadap upaya pemeliharaan gigi tiruan.

Faktor yang turut memengaruhi tingkat kepatuhan sehingga banyak responden memiliki upaya cukup dalam pemeliharaan gigi tiruan ialah lingkungan sekitar responden dan media massa. Hal ini didukung oleh penelitian yang dilakukan oleh Tuerah et al. $^{28}$ di Manado yang menyebutkan hal yang mendorong seseorang dalam perawatan gigi tiruan ialah lingkungan keluarga dan media massa.

Lingkungan sekitar individu merupakan faktor lainnya yang memiliki peranan penting dalam membentuk perilaku kepatuhan individu. Responden bisa mendapatkan informasi atau mencontoh dari individu atau keluarga lainnya di sekitar tempat tinggal, yang memiliki pendidikan lebih tinggi dan memakai gigi tiruan. Faktor lainnya yang menurut penulis juga cukup memberikan pengaruh yaitu media massa. Media massa yang dimaksudkan adalah media elektronik dan media cetak dan media internet. Responden bisa mendapat informasi melalui televisi, koran dan internet yang sudah banyak menampilkan cara pemeliharaan kebersihan gigi dan mulut termasuk cara pemeliharaan gigi tiruan. Media elektronik yaitu televisi yang dulunya termasuk kebutuhan mewah sekarang tidak lagi, karena di zaman yang sudah semakin modern seperti sekarang ini televisi sudah menjadi kebutuhan pokok bagi hampir sebagian besar masyarakat. Asumsi penulis didukung oleh hasil penelitian yang dilakukan Mulyono ${ }^{29}$ di kota Semarang yang menyebutkan 92,31\% keluarga miskin di Kecamatan Gajahmungkur memiliki televisi. Kondisi ekonomi sebagian besar responden yang masih tergolong rendah tidak menjadi alasan bagi responden untuk tidak memiliki televisi di rumah, karena bagi responden televisi 
sudah merupakan kebutuhan yang harus dipenuhi.

Data hasil penelitian pada Tabel 9 memperlihatkan bahwa responden dengan motivasi ekstrinsik rendah sebagian besar $(76,9 \%)$ memiliki kepatuhan rendah, sedangkan responden dengan motivasi ekstrinsik sedang sebagian besarnya $(71,4 \%)$ memiliki tingkat kepatuhan sedang, dan responden dengan motivasi ekstrinsik tinggi tidak ada yang memiliki kepatuhan rendah; melainkan sebagian besar $(57,8 \%)$ memiliki tingkat kepatuhan tinggi. Hasil ini memberikan gambaran bahwa motivasi ekstrinsik seiring sejalan dengan tingkat kepatuhan, atau dengan kata lain motivasi ekstrinsik berpengaruh pada tingkat kepatuhan pemakai gigi tiruan lepasan. Hasil ini terbukti lewat hasil uji statistik regresi sederhana yang dilakukan.

Tabel 10 memperlihatkan hasil uji regresi sederhana dengan nilai signifikasi yang diperoleh $(P=0,000)<0,05$ yang berarti terdapat pengaruh motivasi ekstrinsik terhadap tingkat kepatuhan pemakian gigi tiruan lepasan. Hal ini sejalan dengan penelitian oleh Nirmalawati ${ }^{30}$ di Jember yang menunjukkan semakin tinggi motivasi akan semakin tinggi tingkat kepatuhan $(P=$ $0,000<0,05$ ).

Walaupun responden terbanyak menggunakan GTSL tetapi hasil yang ada belum bisa dikatakan mewakili pengguna GTSL, namun demikian hasil yang ada paling tidak memberikan gambaran adanya pengaruh motivasi ekstrinsik terhadap tingkat kepatuhan pemakai gigi tiruan lepasan yang sebagian besarnya merupakan pemakai GTSL. Limitasi penelitian ini ialah tidak memisahkan antara responden GTSL dan GTP. Kedua responden digabung dan simpulan yang diambil dianggap mewakili keduanya, yakni sebagai pemakai gigi tiruan lepasan.

\section{SIMPULAN}

Berdasarkan hasil penelitian ini dapat disimpulkan bahwa sebagian besar masyarakat Kelurahan Batu Kota pemakai gigi tiruan lepasan memiliki motivasi ekstrinsik dalam penggunaan gigi tiruan kategori sedang dan tingkat kepatuhan dalam menggunakan gigi tiruan kategori sedang

Terdapat pengaruh motivasi ekstrinsik terhadap tingkat kepatuhan pemakai gigi tiruan lepasan di Kelurahan Batu Kota Manado.

\section{SARAN}

Pemerintah dalam hal ini dinas kesehatan dan puskesmas setempat perlu lebih aktif dalam melakukan upaya promo-tif untuk meningkatkan pengetahuan masyarakat yang mendorong masyarakat agar lebih patuh dalam memakai gigi tiruan.

Masyarakat dalam hal ini keluarga dan lingkungan pemakai gigi tiruan lepasan diharapkan lebih berperan untuk memotivasi pemakai gigi tiruan sehingga dapat meningkatkan kepatuhan dalam memakai gigi tiruan.

Dilakukan penelitian lebih lanjut dengan kondisi responden yang lebih bervariasi untuk mengetahui faktor-faktor lain yang berpengaruh pada motivasi dalam hubungannya dengan kepatuhan terhadap pemakaian gigi tiruan lepasan.

\section{DAFTAR PUSTAKA}

1. Francken JE, Sharma P, Stenhouse L, Green D, Laventy D, Dietrich $T$. Global epidemiology of dental caries and severe periodontitis; a comprehensive review. J Clin Periodontol. 2017;44(Suppl 18):S94-S105.

2. Gunadi HA, Margo A, Burhan LK, Suryatenggara F, Setiabudi I. Ilmu Geligi Tiruan Sebagian Lepasan Jilid 1. Jakarta: Hipokrates, 1991; p. 31-9.

3. Petersen PE. The world oral health report 2003. [online] 2003. [cited 2018 Feb 22]. Available from: URL:http:// www. who.int/entity/oral_health/media/en/orh _reports03_en.pdf

4. Wisaty MR, Hadnyanawati H, Suharti. Analisis perbandingan tingkat kepuasan pasien dalam pemakaian protesa gigi tiruan lepasan yang dibuat tukang gigi dan dokter gigi di Kabupaten Jember. Jember: Fakultas Kedokteran Gigi Universitas Jember; 2010.

5. Jubhari EH. Thinking pattern of first grade students towards edentulous replace- 
ment. Dent J (Maj Ked Gigi). 2007;40:65-69.

6. Depertemen Kesehatan Republik Indonesia. Laporan Riset Kesehatan Dasar Nasional 2007. Jakarta: Badan Penelitian dan Pengembangan Kesehatan, 2008.

7. World health organization. Oral health. [serial online]. 2012. [cited 2013 April 22]; Available from: http://www.who.int/ mediacentre/factsheets/fs318/en/index. htm

8. Mitchell L, Mitchell DA, McCaul L. Kedokteran Gigi Klinik Semua Bidang Kedokteran Gigi. Jakarta: EGC, 2014.

9. Rianti, Evi. 2007. Motivasi. [cited 2018 Mar 7]. Available from: http://www.sabda. org/c3i/files/ motivs1.pdf

10. Koehler, Michael and Hal G. Rainey. Interdiciplinary foundations of public service motivation. New York: Oxford University, 2008; p. 33-5.

11. Smet B. Psikologi Kesehatan. Jakarta: Gramedia Widia Sarana, 1994.

12. Loho E. Gambaran efek pemakaian gigi tiruan sebagian lepasan pada pasien di RSGM FK Unsrat [Skripsi]. Manado; Universitas Sam Ratulangi; 2014.

13. Fernatubun CA, Pangemanan DHC, Wowor VNS. Gambaran kerusakan gigi penyangga pada penggunaan gigi tiruan sebagian lepasan di Kelurahan Batu Kota. eG. 2015;3(1):88-93.

14. Agtina MD. Persentase pengguna gigi tiruan di Indonsia. Ejournal Media Litbang; 2010;20(2):50-8.

15. Jatuadomi, Gunawan PN, Siagian KV. Alasan pemakaian gigi tiruan lepasan pada pasien poliklinik gigi di BLU RSUP Prof. Dr. R. D. Kandou Manado. eG. 2016;4(2):40-5.

16. Mokoginta RS, Wowor VNS, Opod H. Pengaruh tingkat pendidikan masyarakat terhadap upaya pemeliharaan gigi tiruan di Kelurahan Upai Kecamatan Kotamobagu Utara. eG. 2016;44(2): 222-8.

17. Badan Pusat Statistik Kota Manado. Jumlah penduduk Kota Manado Menurut Kelompok Umur 2011 - 2016 - BS Available from: https://manadokota. bps.go.id

18. Prabhu N, Kumar S, D'souza M, Hegde V. Partial edentulousness in a rural population based on Kennedy's classify- cation: An epidemiological study. J Prosthodont. 2009;9:18-23.

19. Pallagedara C, Ekanayake L. Tooth loss the wearing of dentures and associated factors in Sri Langka older individual. Gerodontology. 2010;22(4):193-9.

20. Atmaja RAJ, Rahmatika R. Peran dukungan social keluarga terhadap motivasi menjaga kesehatan melalui aktivitas fisik pada lansia. Jurnal Psikogenesis. 2017:5(2):180-7.

21. Oftedal BF. Motivation for self-management among adult with type 2 Diabetes. [Tesis]. Stavenger: Faculty of Social Sciences University of Stavanger; 2011.

22. Sumolang M. Peranan internet terhadap generasi muda di Desa Tounelet Kecamatan Langowan Barat. Jurnal Acta Diurna. 2013:2(4).

23. Calvin GM, Pintauli S. Pemanfaatan informasi tentang kesehatan gigi dan mulut yang diperoleh dari internet melalui gadget di Kota Medan [Skripsi]. Medan: Fakultas Kedokteran Gigi Universitas Sumatera Utara; 2017.

24. Anorital, Muljati S, Andayasari L. Gambaran ketersediaan tenaga dan upaya pelayanan kesehatan gigi di Puskesmas. Buletin Penelitian Kesehatan 2016;44(3):197-204.

25. Herwanda, Novita CF, Berutu MP. Peran motivasi terhadap tingkat kooperatif pasien yang berkunjung ke Rumah Sakit Gigi dan Mulut UNSYIAH. Dentistry Society. 2017:2(1):73-7.

26. Tombokan V, Rattu AJ, Tilaar CR. Faktorfaktor yang berhubungan dengan kepatuhan berobat pasien diabetes mellitus pada praktek dokter keluarga di Kota Tomohon. JIKMU. 2015: 5(3):260-9.

27. Febrianto ID. Hubungan tingkat penghasilan, tingkat pendidikan dan tingkat pengetahuan orang tua tentang makanan bergizi dengan status gizi siswa TK Islam Zahrotul Ulum Karangampel Indramayu [Skripsi]. Yogyakarta: Fakultas Ilmu Keolah-ragaan Universitas Negeri Yogyakarta; 2012.

28. Tuerah T, Wowor VNS, Pangemanan DHC. Hubungan status ekonomi dengan sikap pasien terhadap perawatan gigi tiruan. Pharmacon. 2016; 5(1):66. 
29. Mulyono SE. Model pemberdayaan masyarakat miskin melalui jalur pendidikan non formal di Kecamatan Gajahmungkur Kota Semarang. Jurnal Unnes. 2011;1:4.

30. Nirmalawati L. Hubungan motivasi pasien datang ke rumah sakit gigi dan mulut Universitas Jember terhadap tingkat kooperatif pasien [Skripsi]. Jember: Fakultas Kedokteran Gigi Universitas Jember; 2012. 